NBER WORKING PAPER SERIES

AMIDST POVERTY AND PREJUDICE:

BLACK AND IRISH CIVIL WAR VETERANS

Hoyt Bleakley

Louis Cain

Joseph Ferrie

Working Paper 19605

http://www.nber.org/papers/w19605

\author{
NATIONAL BUREAU OF ECONOMIC RESEARCH \\ 1050 Massachusetts Avenue \\ Cambridge, MA 02138 \\ October 2013
}

This work was supported in part by NIH program project grant P01 AG10120, Early Indicators of Later Work Levels, Disease and Death. The authors are grateful to Alex Orsini for his help with the data and to Dr. Lauren Cain for her help with epidemiological considerations. We thank Joey Burton, Tim Classen, Dora Costa, Sok Chul Hong, and the participants at the Northwestern Conference in Honor of Joel Mokyr and the Workshop on the Economics and Biodemography of Aging at the University of Chicago Booth School of Business for their comments. The views expressed herein are those of the authors and do not necessarily reflect the views of the National Bureau of Economic Research.

NBER working papers are circulated for discussion and comment purposes. They have not been peerreviewed or been subject to the review by the NBER Board of Directors that accompanies official NBER publications.

(C) 2013 by Hoyt Bleakley, Louis Cain, and Joseph Ferrie. All rights reserved. Short sections of text, not to exceed two paragraphs, may be quoted without explicit permission provided that full credit, including $(\mathcal{C}$ notice, is given to the source. 
Amidst Poverty and Prejudice: Black and Irish Civil War Veterans

Hoyt Bleakley, Louis Cain, and Joseph Ferrie

NBER Working Paper No. 19605

October 2013

JEL No. N11

\begin{abstract}
$\underline{\text { ABSTRACT }}$
This study examines a wide range of health and economic outcomes in a sample of Irish- and AfricanAmerican Civil War veterans during the postbellum period. The information in our data is from a variety of circumstances across an individual's life span, and we use that to attempt to explain whether the disparities in mortality are related to disparities in life experiences. We find evidence of disparities between Irish and blacks and others in such variables as occupation and wealth, morbidity, and mortality. The data do not reveal disparate outcomes for all blacks and Irish; they only reveal inferior outcomes for slave-born blacks and foreign-born Irish. For the freeborn blacks and native-born Irish, for whom the historical tradition suggests discrimination and prejudice, the data only hint at such problems.
\end{abstract}

\author{
Hoyt Bleakley \\ Booth School of Business \\ University of Chicago \\ 5807 South Woodlawn Avenue \\ Chicago, IL 60637 \\ and NBER \\ bleakley@chicagobooth.edu

\section{Louis Cain} \\ Department of Economics \\ Loyola University Chicago \\ 820 N. Michigan Ave. \\ Chicago, IL 60611 \\ and NBER \\ lcain@luc.edu
}

Joseph Ferrie

Department of Economics

Northwestern University

Evanston, IL 60208-2600

and NBER

ferrie@northwestern.edu 


\title{
Amidst Poverty and Prejudice: Black and Irish Civil War Veterans
}

\author{
Hoyt Bleakley, Louis Cain, Joseph Ferrie ${ }^{1}$
}

To hate all but the right folks

Is an old established rule.

Tom Lehrer, "National Brotherhood Week"

With razor-sharp sarcasm, satirist Tom Lehrer reminded his listeners that prejudice and discrimination were well-established phenomena. In the early 1960s, one could still find signs reading "Colored Entrance" throughout the American South. It was widely believed that signs reading "No Irish Need Apply" were equally ubiquitous in Northern cities at the turn of the twentieth century. While historian Richard Jensen has argued persuasively that this was largely a myth, the sentiment was real. ${ }^{2}$ The main concern was their Catholicism, but the Irish also provoked fear among Americans because of their use of violence. Irish men often worked at job sites that were controlled through the force of Irish gangs; Irish women were often domestics. As famine wracked their homeland, the Irish migrated in mass to the U.S. Despite the fears, there was no attempt to exclude them.

At different times in U.S. history, these two groups, the Irish and the blacks, supplied the unskilled labor on which a rapid rate of industrialization depended. For the latter half of the nineteenth century, it was the Irish immigrants. By the early years of the twentieth century, with the reduction of immigration from Europe, the "Great Migration" of blacks northward maintained needed labor supplies. In cities such as Lowell, Massachusetts, the first transition was dramatic. ${ }^{3}$ Ninety percent of the labor force was reported to be native born in 1849 , many of them of Irish ancestry. Six years later, only 35 percent were native born; the balance were immigrants, largely from Ireland. This contributed to the "de-skilling" of the labor force (whereby unskilled workers gradually replaced skilled craftsmen as capital substituted for labor) and to the rise of the "Know-Nothing" Party (which was particularly strong in de-skilled areas).

As industrialization preceded apace, scholars such as Oscar Handlin, who studied the Irish in Boston, found they were at the bottom of the occupational hierarchy. ${ }^{4}$ Other scholars note that the Irish and free blacks lived in the same neighborhoods and intermarried in the antebellum period. ${ }^{5}$ Like the blacks, the Irish were often unskilled, innumerate, and subjected to discrimination. Notes Joel Mokyr: 
The Irish in Handlin's Boston were excluded from more desirable professions not only by the prejudice and suspicion of others, but because of their lack of capital and training. Even the blacks, most similar to the Irish in occupational experience, did better than they did.... Even in peddling and groceries to their own kinsmen the Irish seem to have done poorly in the USA in contrast to Britain ..., which is fully consistent with our finding that the percentage of overseas emigrants in commercial occupations was very low and that they were, on the whole, not very numerate. ${ }^{6}$

After the Civil War, as industrialization firmly took hold, the Irish and the blacks were still near the bottom of the socio-economic hierarchy, but there were some changes. The movement of southern blacks northward, albeit not in the magnitudes of the "Great Migration," was still large enough to cause a deterioration in the relative position of northern blacks. The arrival of other Roman Catholic immigrants from southeast Europe, many without the ability to speak English, led to an increase in the relative position of the Irish. Withal, this is still the period when prejudice against the Irish is characterized by the idea that "No Irish Need Apply."

This study examines a wide range of health and economic outcomes in a sample of Irishand African-American Civil War veterans in the second half of the nineteenth century. We find evidence of disparities between Irish and blacks and others in such variables as occupation and wealth, morbidity and mortality. The information in our data is from a variety of circumstances across the span of an individual's life, and we use that to attempt to explain whether the disparities in mortality are related to disparities in life experiences.

Our data were collected under the auspices of Robert Fogel's Early Indicators of Later Work Levels, Disease, and Death project at the University of Chicago's Booth School of Business. ${ }^{7}$ The Early Indicators life-cycle health histories of Union Army veterans contained in the databases of the Center for Population Economics (CPE) provide insight into how well these two groups did relative to other veterans in the post-bellum period. The Union Army Data Set (UA) consists of the military, pension, census and lifetime medical records of white men from 25 Northern states who served as infantrymen in 331 companies in the Union Army during the Civil War. The U.S. Colored Troops (USCT) data set consists of identical records of black men who served as infantrymen in 52 companies of the Union Army during the war. ${ }^{8}$

For present purposes, the sample was limited to veterans who did not desert, who survived the war, and for whom an age at death is available. White officers were excluded from 
the USCT data. Whites in the UA database, both Irish and non-Irish, were divided into those born in the U.S. (native-born) and elsewhere (foreign-born). Blacks have been subdivided into those born in free-states and those born in slave states (as those states were considered in 1837). ${ }^{9}$ Table 1 contains the counts of veterans in each of the three groups (plus two subgroups for each group) and in the total that led to our final sample of 19,951 veterans used in the analyses that follow. For expository purposes, the four columns expressing subtractions from the initial total are expressed as percentages of the initial sample size.

Table 1 highlights several differences among the groups and subgroups. The foreignborn whites were much more likely to desert than the native-born; the two subgroups of Irish were less likely to desert than the respective subgroup of non-Irish. The native-born Irish had a rate similar to USCT born in a free-state, while USCT born in slave-states had the lowest rate of desertion. However, the slave-born USCT were 50 percent more likely to die in service than native-born non-Irish; the native-born Irish having a remarkably low rate. Finally, the database is much less likely to have an age of death for foreign-born non-Irish and blacks, whether freeborn or slave-born.

\begin{tabular}{|c|c|c|c|c|c|c|c|}
\hline \multicolumn{8}{|c|}{ Table 1: Sample Counts } \\
\hline & Group $^{1}$ & $\begin{array}{c}\text { Initial } \\
\text { Sample }\end{array}$ & Deserted & Officer $^{2}$ & $\begin{array}{c}\text { Died in } \\
\text { Service }^{3}\end{array}$ & $\begin{array}{l}\text { No Age } \\
\text { at Death }\end{array}$ & $\begin{array}{c}\text { Final } \\
\text { Sample }\end{array}$ \\
\hline \multirow[t]{3}{*}{ A. } & Non-Irish UA & 33,767 & $15.40 \%$ & $0.56 \%$ & $15.30 \%$ & $30.40 \%$ & 16,748 \\
\hline & A.1 Native Born & 24,480 & $12.10 \%$ & $0.69 \%$ & $15.70 \%$ & $23.10 \%$ & 13,704 \\
\hline & A. 2 Foreign Born & 7,987 & $24.50 \%$ & $0.20 \%$ & $11.60 \%$ & $50.70 \%$ & 2,715 \\
\hline \multirow[t]{3}{*}{ B. } & USCT & 6,155 & $8.60 \%$ & $3.90 \%$ & $23.30 \%$ & $39.50 \%$ & 2,094 \\
\hline & B.1. Born in Slave State & 5,049 & $8.80 \%$ & $0.16 \%$ & $24.40 \%$ & $37.80 \%$ & 1,869 \\
\hline & B.2. Born in Free State & 636 & $9.30 \%$ & $22.80 \%$ & $12.90 \%$ & $39.50 \%$ & 179 \\
\hline \multirow[t]{3}{*}{ C. } & Irish $^{4}$ & 1,817 & $15.80 \%$ & $0.33 \%$ & $7.30 \%$ & $23.30 \%$ & 1,110 \\
\hline & C. 1 Native Born & 469 & $9.40 \%$ & $0.43 \%$ & $0.60 \%$ & $5.80 \%$ & 395 \\
\hline & C.2. Foreign Born & 1,339 & $18.10 \%$ & $0.30 \%$ & $9.70 \%$ & $29.40 \%$ & 710 \\
\hline D. & Total & 41,725 & $14.40 \%$ & $1.04 \%$ & $16.10 \%$ & $31.40 \%$ & 19,951 \\
\hline
\end{tabular}


Notes:

${ }^{1}$ Recruits' (and their parents's) places of birth were determined using information found in their pension, military service, and census records. The non-Irish UA are divided into two subgroups: Native Born and Foreign Born. The former includes all recruits born in any of the present-day United States. The latter includes recruits with a birthplace outside of the United States. Irish is defined as any recruit born in Ireland or with at least one parent born in Ireland. This group is also divided into Native Born and Foreign Born groups, but the latter category only includes recruits born in Ireland. Finally, the USCT are divided into two groups: those born in slave states and those born in free states (as defined in 1837).

${ }^{2}$ We dropped any recruit that ever became an officer from the black sample and only those recruits that started as officers from the Irish and non-Irish UA samples.

${ }^{3}$ Includes all recruits that died during the war or while still enlisted in the service. For example, black troops that enlisted in 1863 (with a three year contract) and died fighting in frontier battles or during the march home in 1866 were excluded from our final sample.

${ }^{4}$ Sub-group totals do not equal sum of parts because birthplace was not available for all recruits.

Using the individuals in the "Final Sample" in Table 1, we want to look at how mobile they were - where did they live before and after the war? In addition to their geographic mobility, we want to look at their occupational mobility; not all of them were at the bottom of the hierarchy. How many succeeded and where? We then will compare their health status by looking at the incidence of disease and their cause of death. Finally, we will look at survival rates of the various groups and calculate hazard ratios. First, however, we must discuss how we determine who is Irish - and how we can enlarge the sample.

\section{Who is Irish?}

The Union Army data includes 1,817 individuals that we know were born in Ireland or whose parents were born in Ireland. There are many more people with Irish surnames in the database. Some of these are third-generation (or more) Irish, for we know that neither they nor their parents were born in Ireland. Unfortunately, complete information is not available on veteran's birthplaces, much less their parents' birthplaces, and there are many individuals for whom information is lacking to establish what generation American they are or whether they belong to a particular ethnic group.

Since some information required for our analyses involves linkage to U.S. censuses, and since roughly two-thirds of the names in the Union Army database could not be linked conclusively to the 1860 census, the 1,110 individuals contained in the final sample constitutes too small a number to address some of our questions. Thus, to augment the sample, we turned to the IPUMS One Percent Sample of the 1850, 1860, and 1870 censuses. We searched for 
surnames where at least 25 people had that surname and 80 percent or more of them were born in Ireland. The first restriction was to have sufficient numbers to suggest the name was not the result of a single family; the second, to make sure they were largely Irish. This generated a list of 201 surnames. In several cases, different spellings of names that would be pronounced the same were captured by this rule (e.g., Cain-Kane, Conner-Connor-O'Connor, Kelley-Kelly, O'Neal-O'Neil). As a result, we chose not to augment the list with additional homonyms (e.g., Kain or O'Neill) that did not satisfy the two restrictions. This approach added a total of 502 individuals to the 1,110 originally identified to give us a total sample of 1,612 individuals.

The consequences of this definition were explored by examining several demographic statistics for the resulting sample against those of alternative rules of defining an Irish surname using the IPUMS sample. For example, a more restrictive definition might require that there be at least 50 people with a given surname; a less restrictive definition, 10 people. All three cases assume that 80 percent or more of them were born in Ireland. Table 2 reports the results. Changing the rule for determining whether someone is Irish leads to minor changes in the summary statistics: the less restrictive the rule, the greater the percentage of rural veterans that are included. They are only slightly taller and are less long-lived, which means lower survival rates. This table supports the decision to define Irish in this manner, but alternative definitions need to be explored. ${ }^{10}$ Changes in the rule for determining whether someone is Irish lead to only small changes in these summary statistics. ${ }^{11}$

\begin{tabular}{|l|l|l|l|l|l|}
\hline Table 2: Comparison of Alternative Rules for Irish Surname \\
\hline & & $\begin{array}{c}\text { More } \\
\text { Restrictive }\end{array}$ & $\begin{array}{c}\text { Our } \\
\text { Sample }\end{array}$ & $\begin{array}{c}\text { Less } \\
\text { Restrictive }\end{array}$ & \\
\hline & & & \\
\hline Measure & 1,437 & 1,612 & 1,848 \\
\hline & Height (inches) & 67.42 & 67.46 & 67.52 \\
\hline Age at Death & 69.04 & 68.61 & 68.56 \\
\hline \% Rural at Enlistment & 60.03 & 61.44 & 62.8 \\
\hline Survival Rate (1865-1900) & 72.37 & 70.86 & 70.35 & \\
\hline
\end{tabular}

In Table 3, we use the variables reported in Table 2 to compare the different groups and subgroups. Height is correlated with both economic well-being and health. For non-Irish whites, the average native-born veteran was just under five feet, eight inches tall, with the 
average foreign-born veteran approximately an inch shorter. The average native-born Irish white was the same height as the average non-Irish white (combining the native- and foreign-born), but the foreign-born Irish were two-thirds of an inch shorter than their native-born counterparts. The colored troops born in a free state were a half-inch shorter than the average Irish troops (again combining the native- and foreign-born), while the slave-born USCT were a third of an inch shorter than their freeborn counterparts. Thus, there is a 1.3-inch difference in the average height of the tallest and shortest subgroup. It is no surprise that this measure suggests the health trajectory of slave-born blacks was poorer than native-born whites.

With respect to age at death, the non-Irish lived to an average age of 69.1 years with the Irish living about six months less. The native-born Irish lived a bit longer than the native-born non-Irish, and they proved to be the longest lived of the subgroups. The foreign-born non-Irish lived six month shorter lives than the native-born non-Irish, but 10 months longer than the foreign-born Irish did. The foreign-born Irish, in turn, lived about twenty months longer than the freeborn USCT. The shortest-lived of any group was the slave-born USCT who lived to an average age of only 65.3 years, more than four years less than the native-born Irish.

\begin{tabular}{|l|l|r|r|r|r|r|r|}
\hline \multicolumn{9}{|c|}{ Table 3 : Comparison of Various Groups and Subgroups } \\
\hline
\end{tabular}

The pattern in the survival rates of whites reflects the pattern in the average year of birth. The native-born non-Irish and Irish are younger than the foreign-born and a larger percentage of them are alive in 1900. The native-born Irish are about a year and four months younger, while 
the foreign-born Irish are about three years younger than the native-born non-Irish. USCT who were born in free states were roughly a half-year younger than the native-born non-Irish, but their survival rates were several percentage points lower than what might have been predicted from the white experience. The USCT born in slave states were born, on average, at the same time as the native-born non-Irish, but the survival rate among those who survived the war was even lower than those born in free states.

The final column reports the percent that were recorded as living in a rural area when they enlisted. Urban areas were defined as places where 2,500 or more individuals lived, so many of the "urbanites" are from quite small places. The freeborn blacks are the most urbanized by far; with a majority of them living in such places. The native-born non-Irish are the most rural, with almost 80 percent of them reported as such; slave-born blacks are next at about 75 percent. The native-born non-Irish and Irish are more rural than their foreign-born counterparts, with a thin majority of the foreign-born Irish classified as rural.

\section{Geographic Mobility}

There are two types of mobility to be investigated: geographic and occupational. Geographic mobility of the two ethnic groups can be seen in the following figures. First, consider the Irish. In Figure 1, we consider only those born in the United States. Of these, 52.7 percent were born in the Northeast, with another 38.3 percent born in the Midwest. By way of contrast, about 47.7 percent of the native-born non-Irish Union Army veterans were born in the Northeast, with 41.1 percent born in the Midwest. In Figure 2, we see where the Irish enlisted for the war, and the same distribution is present, with the percentages for the non-Irish whites at roughly 32.7 percent in the Northeast and 58.6 percent in the Midwest. 
Figure 1: Irish Birthplaces in the US

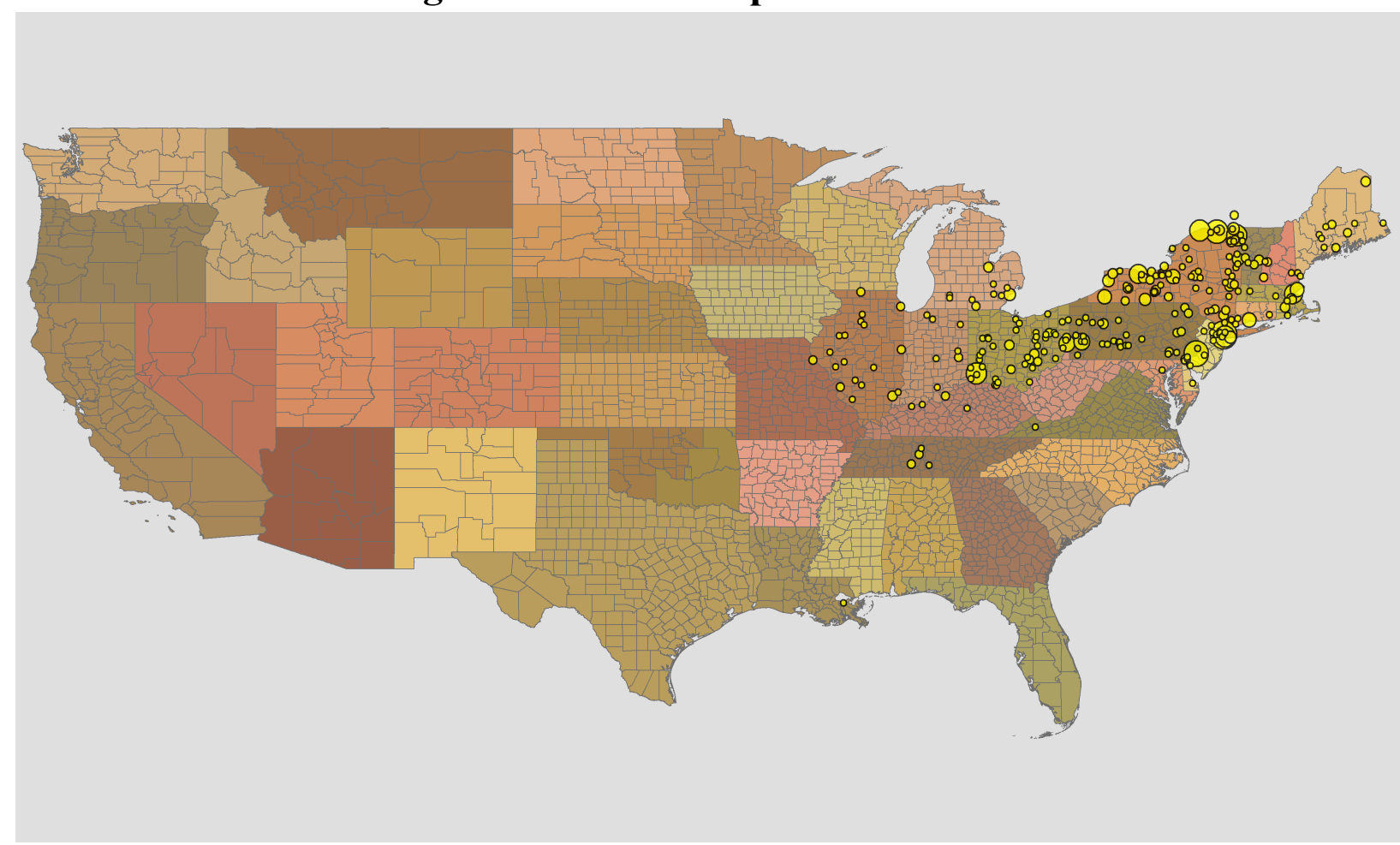

Figure 2: Irish Enlistment Locations

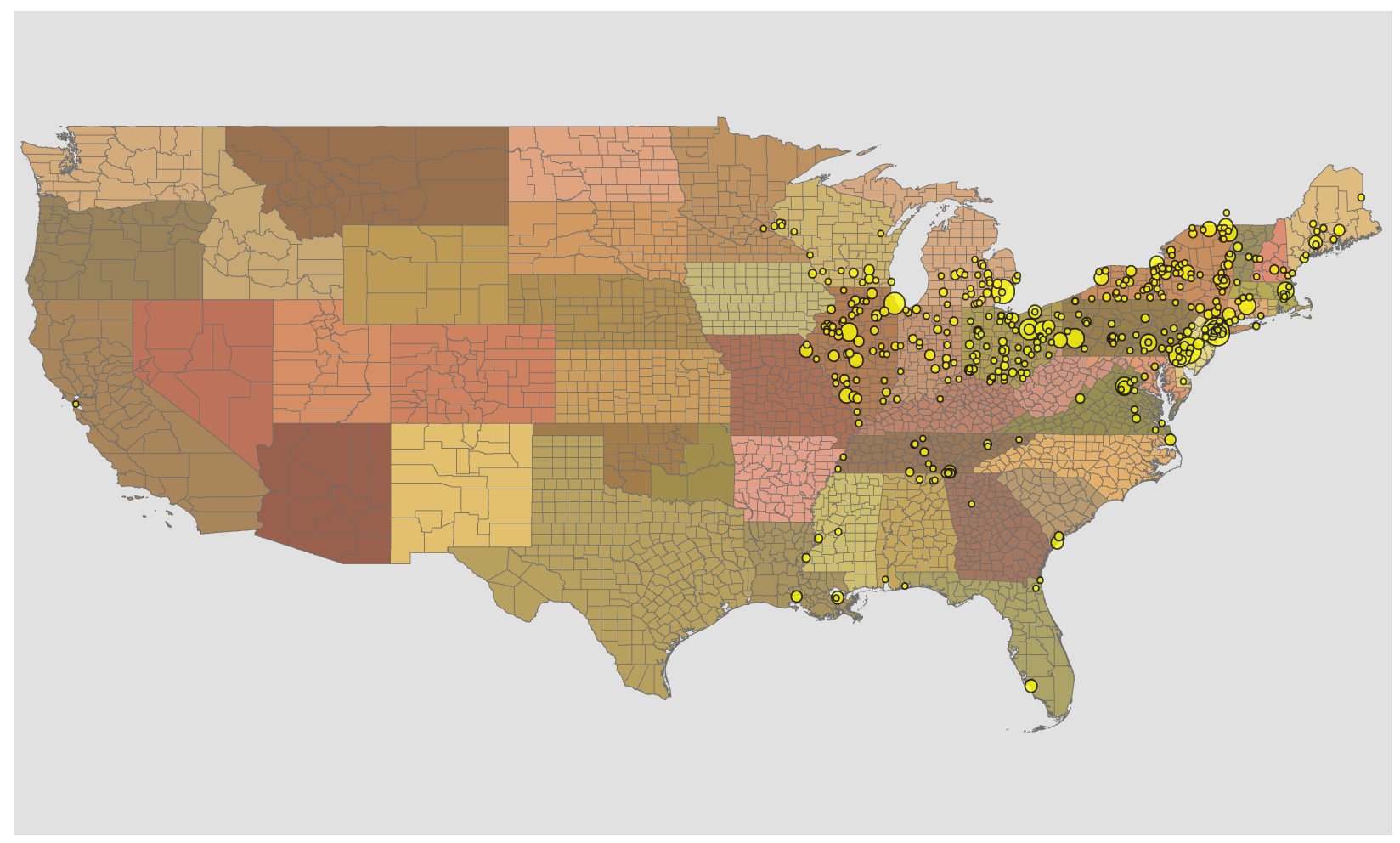




\section{Figure 3: Irish Locations 1890}

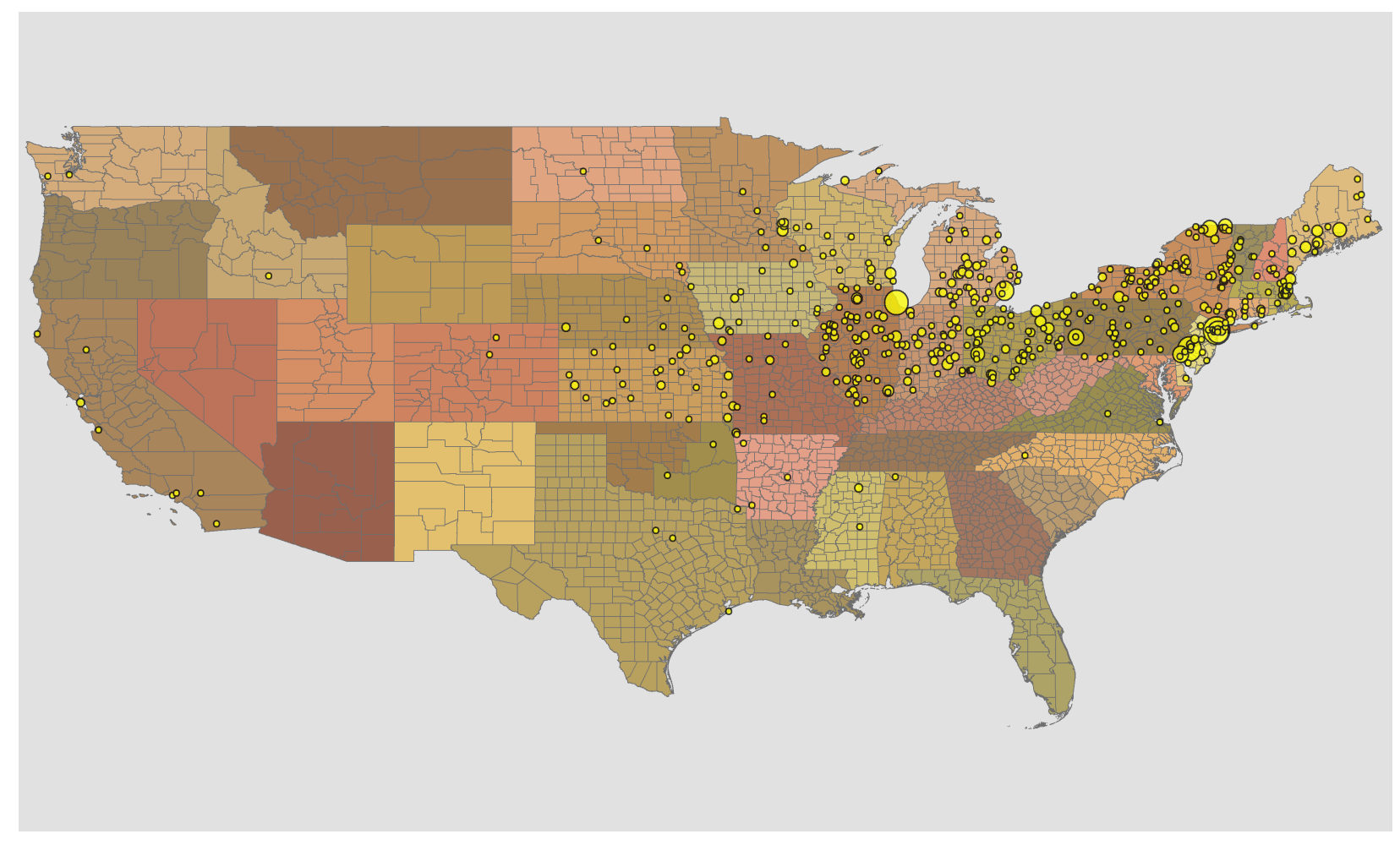

The growth of Detroit and Chicago is evident. At enlistment, we can divide the Irish into those who were born in the United States and those who were born in Ireland. The native-born Irish have already begun to migrate; only 36.3 percent of them remain in the Northeast, but 57.8 percent of the foreign-born enlist there. 55.2 percent of the native-born are now in the Midwest as compared to 35.0 percent of the foreign born.

By 1890, as Figure 3 depicts, the percentages for the two regions have reversed for all Irishmen (35.6 percent Northeast vs. 54.0 percent Midwest). By this time, the foreign-born also have begun to migrate west, as the Northeast was home to only 26.2 percent of the native-born and 44.9 percent of the foreign-born. The Midwest was home to 63.4 percent of the native-born and 44.6 percent of the foreign-born. The non-Irish exhibited a similar pattern as the native-born Irish. 
Figures 4-6 provide the same information for blacks. Of the USCT, 88.5 percent were born in the South, with 5.2 percent born in the Northeast and 6.3 percent born in the Midwest. Of the native freeborn, 61.5 percent were born in the Northeast with 8.0 percent in the Midwest, and 30.5 percent in the South (as defined by the census as opposed to the Confederacy). Perhaps a tenth of those categorized as freeborn were born outside the country. Of the slave-born, 93.9 percent were born in the South, with the balance in border states. The birthplaces of USCT are shown in Figure 4.

The places of enlistment are roughly similar to birthplaces, with 80.1 percent in the South, but the balance is roughly evenly split between the Northeast and Midwest. For the freeborn, 66.1 percent enlisted in the Northeast, 7.1 percent in the Midwest, and the balance, 26.8 percent, in the South. For the slave-born, 85.0 percent enlisted in the South, with 4.9 percent in the Northeast (particularly the Middle Atlantic) and 10.0 percent in the Midwest (particularly the West North Central). The places of enlistment are in Figure 5.

In $1890,70.4$ percent of the USCT are still in the South. This includes 21.8 percent of the freeborn and 74.5 percent of the slave-born. The largest share of the former are in the MidAtlantic, while the largest share of the latter are in the East South Central regions. Of the USCT, 7.7 percent are in the Northeast. That area is home to 50.0 percent of the freeborn veterans, the vast majority of whom live in the Middle Atlantic region, but only 4.1 percent of the slave-born live in the industrializing Northeast. The Midwest has become home to 20.7 percent of the USCT, with 24.4 percent of the freeborn and 20.4 percent of the slave-born residing there. Of those living in the Midwest, the East North Central was home to 21.8 percent of the freeborn, while the West North Central was home to 12.7 percent of the slave-born. The result is in Figure 6. 
Figure 4: Black Birthplaces

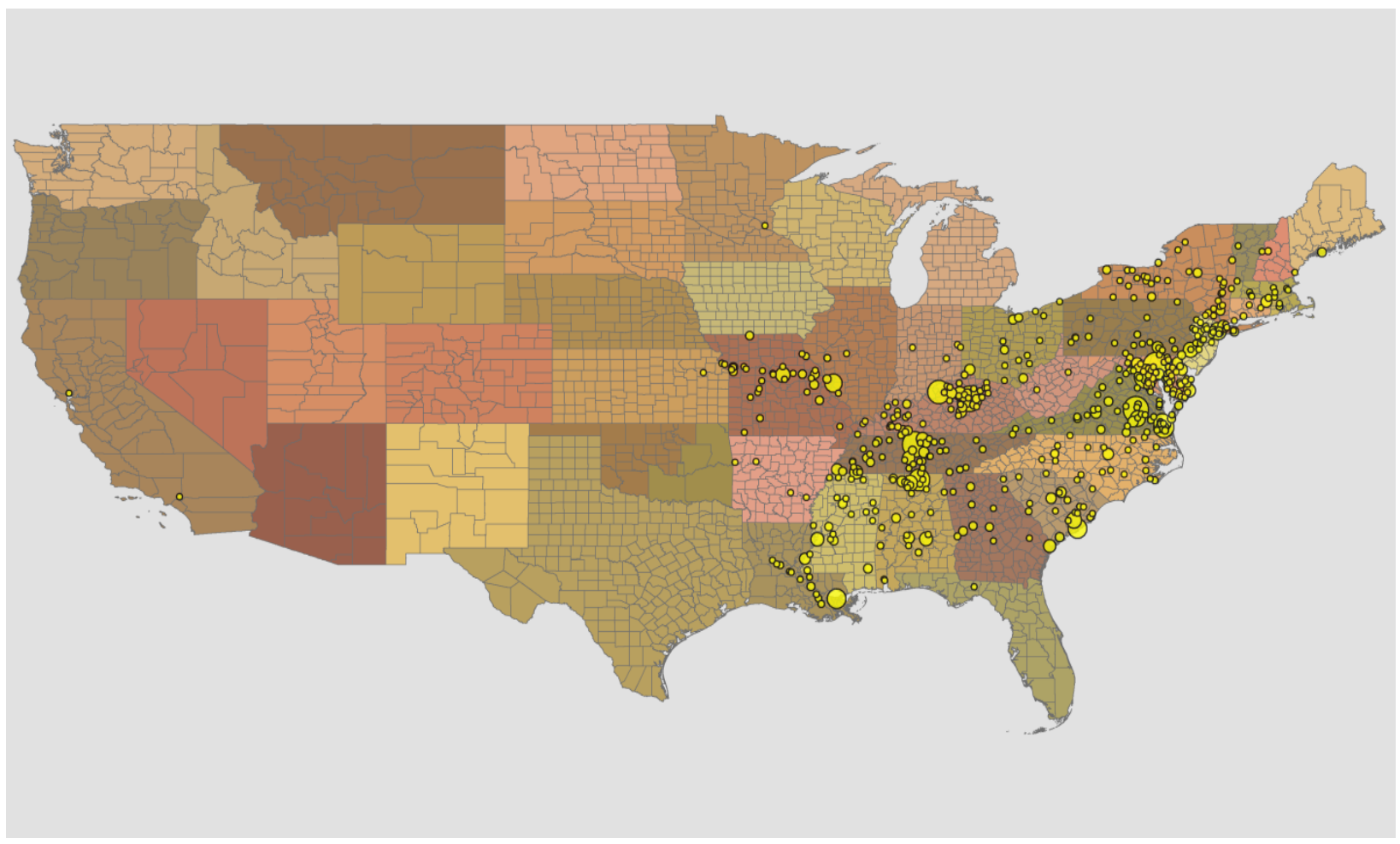

Figure 5: Black Enlistment Locations

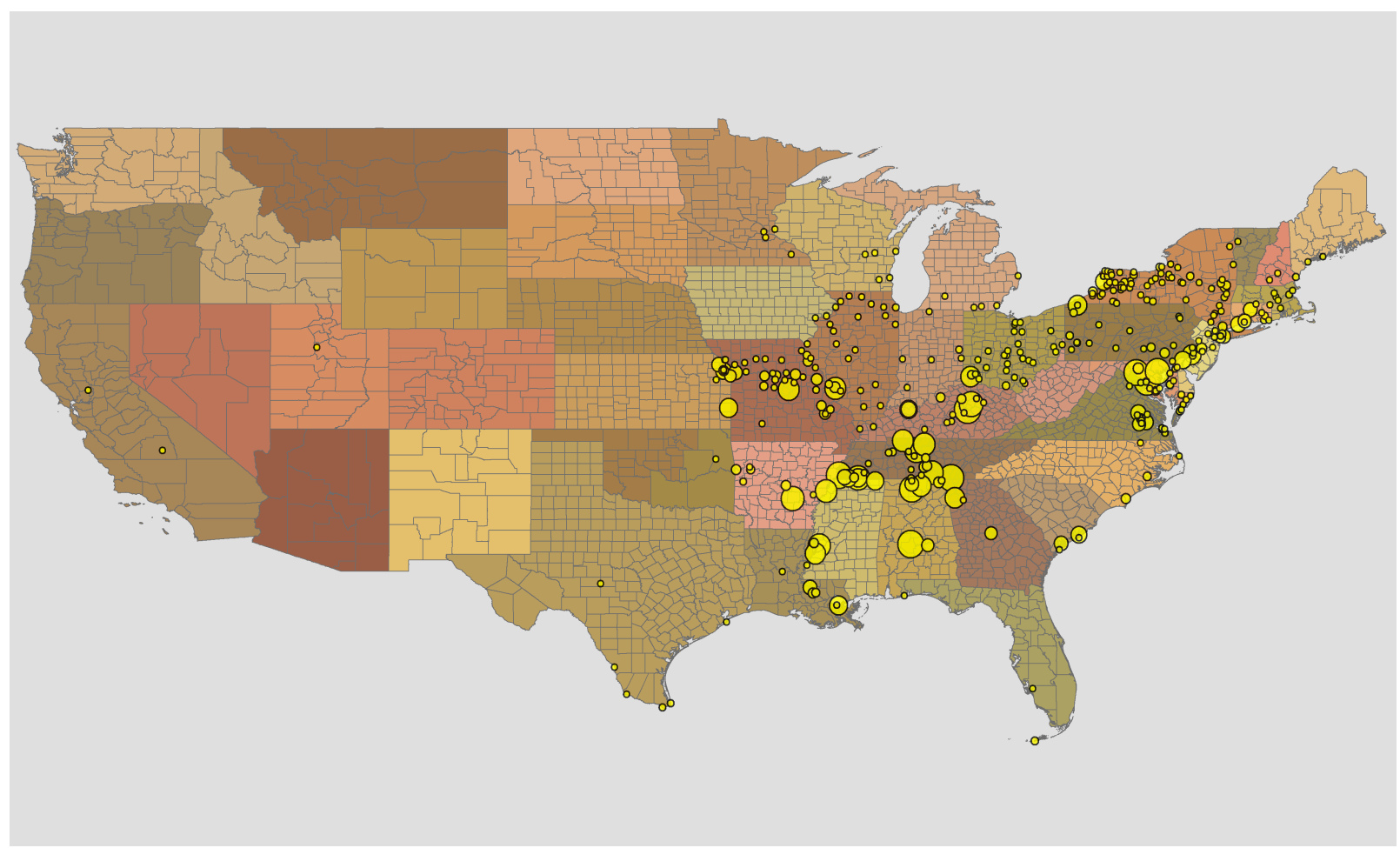




\section{Figure 6: Black Locations 1890}

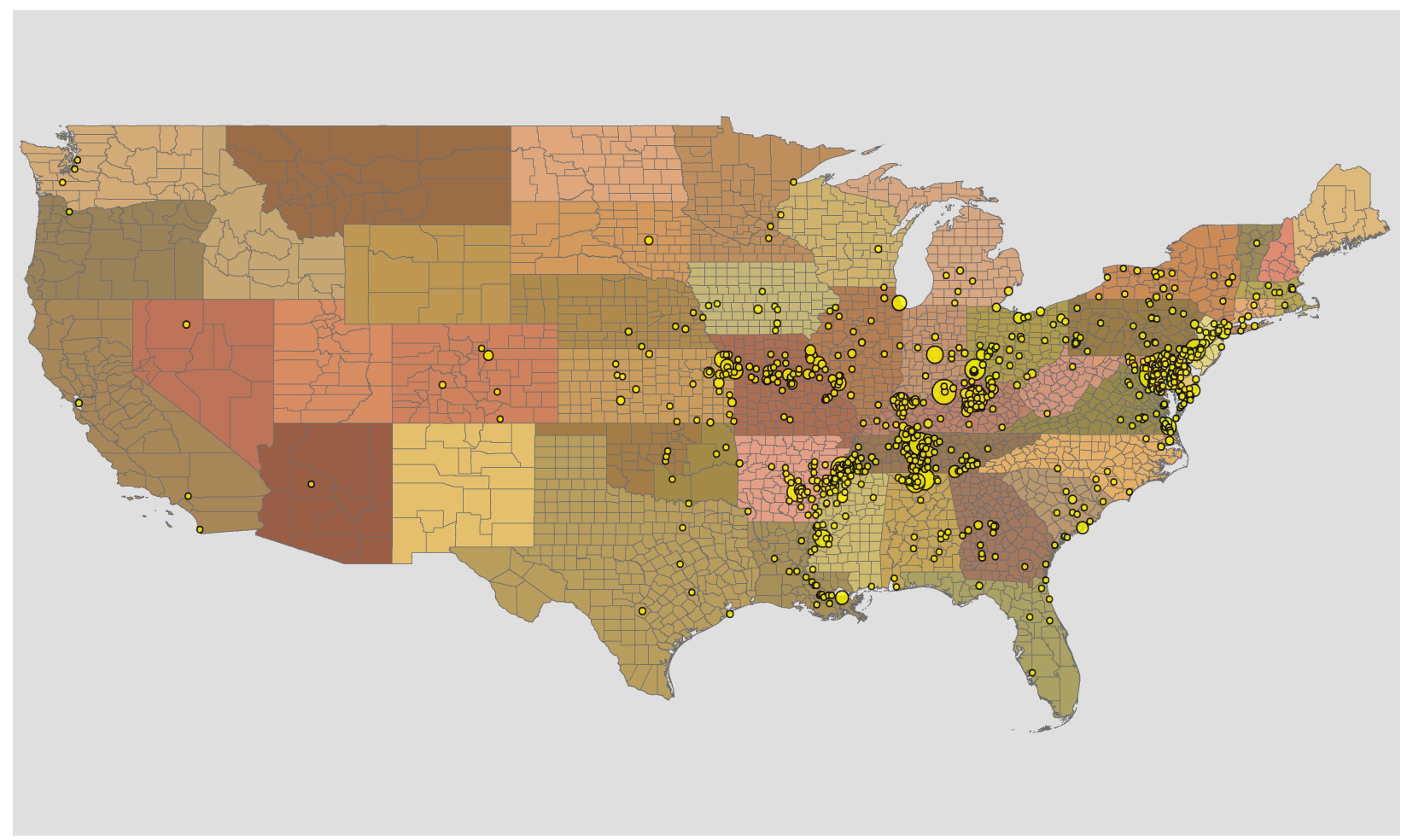

Overall, the USCT were far less mobile than the native-born Irish and the non-Irish UA veterans. The problems faced by the slave-born are well known; nevertheless some of them are beginning to move north and west by 1890 . The freeborn are slightly more mobile than the slave-born, but they too are less mobile than whites.

\section{Occupational Mobility}

The second type of mobility to be considered is occupational mobility. We have adopted a six-way occupational distribution: high- and low-skill white-collar, farmer, high (skilled) and low (semiskilled) blue-collar, unskilled, with the balance being unclassified. We have two snapshots of these populations. The first is from the enlistment records, while the latter is from the 1890 census. The former is reported in Table 4; the latter, Table 6. 


\begin{tabular}{|r|r|r|r|r|r|r|r|r|r|r|r|}
\hline \multicolumn{9}{|c|}{ Table 4: Occupational Distribution of UA, USCT, and Irish in 1863} \\
\hline \\
\hline
\end{tabular}

The similarities between the native-born and foreign-born Irish and non-Irish are immediately apparent. The foreign-born are much less likely to be farmers and much more likely to be unskilled, often industrial, workers. There are relatively fewer of them in the high white-collar positions, and relatively more in blue-collar positions. The slave-born are overwhelmingly either farmers or unskilled. The same is true of those born in free states, but the proportions of the two are reversed. They are more likely to be semiskilled than any group other than the foreign-born Irish. On the other hand, they are completely missing from white collar occupations. $^{12}$

It seems natural to inquire if this occupational distribution is consistent with other readily available information. These results are consistent with those in a sample assembled by Glatthaar for his study of the USCT, the census data assembled by Horton and Horton for their study of free blacks in Boston before the Civil War, and a sample assembled by Curry of free urban blacks in the antebellum period. ${ }^{13}$ In particular, Joel Mokyr calculated a 14-way distribution for both the 1841 Irish census and for the records of Irish migrants arriving in New York City in the years before the famine of 1848. We have compressed his 14 categories into our six. Table 5 compares those results with the foreign-born Irish from Table $4 .{ }^{14}$ 


\begin{tabular}{|r|l|r|r|r|}
\hline \multicolumn{2}{|c|}{ Table 5: Irish Census, ship registers, and enlistment } \\
\hline \multicolumn{2}{|c|}{$(p e r c e n t a g e s)$} \\
\hline
\end{tabular}

It is likely the data from the 1840 s and earlier reflect an older generation than that from the 1860s. Overall, white-collar workers are roughly the same total percentage in all three columns. The fact the percentage in high white-collar occupations is smaller in 1863 could be due to those that might have been in that group being officers or buying their way out of the service. The percent of Irish-born enlistees who were farmers is somewhat higher than the percentage in the 1841 census and ship registers. ${ }^{15}$ There is rough consistency between the census and ship registers as to the percentage of high blue collar workers, but this increases dramatically in the enlistment records. And while the percent unskilled is higher in the ship registers than the 1841 census, it is much lower in the enlistment records. While many of the enlistee's fathers may have reported being unskilled, the enlistees themselves learned a skill in the family's new country and worked either on farms or in high blue collar occupations. There does not appear to be much movement toward the higher-earning part of the distribution from the 1840 s to the 1860 s.

Three decades later, the percentage breakdown from the 1890 census for the non-Irish and Irish in Table 6 shows increasing numbers of white-collar workers and a decline in the number of farmers, as one would expect during this period of industrialization. The percentage of high white-collar jobs has increased more for the native-born than the foreign-born, and more for the non-Irish than the Irish. The Irish have seen more or less equal advancement for low whitecollar jobs. Otherwise, the distributions are quite similar. The difference between the nativeborn and foreign-born Irish has narrowed, but much larger percentages of the foreign-born are still being reported in either semiskilled blue-collar jobs or as unskilled. 


\begin{tabular}{|c|c|c|c|c|c|c|c|c|c|c|}
\hline \multicolumn{11}{|c|}{ Table 6: Occupational Distribution of UA, USCT, and Irish in 1890} \\
\hline & & & & & & & & & & \\
\hline & & \multicolumn{3}{|c|}{ Non-Irish UA } & \multicolumn{3}{|c|}{ USCT } & \multicolumn{3}{|c|}{ Irish } \\
\hline & & Total & Native & Foreign & Total & Free & Slave & Total & Native & Foreign \\
\hline & $\mathrm{N}$ & 11,652 & 9,764 & & 1,573 & 135 & 1,414 & & 586 & 566 \\
\hline 6 & High White Collar & 6.45 & 6.76 & 4.83 & 2.29 & 5.93 & 1.91 & 4.64 & 5.12 & 4.24 \\
\hline 5 & Low White Collar & 4.65 & 4.73 & 4.42 & 0.45 & 0.00 & 0.42 & 5.06 & 6.14 & 4.06 \\
\hline 4 & Farmer & 45.14 & 46.30 & 37.95 & 27.78 & 8.89 & 29.77 & 34.85 & 39.76 & 28.98 \\
\hline 3 & High (Skilled) Blue Collar & 18.03 & 17.27 & & 4.70 & 2.22 & 4.95 & 19.48 & 20.48 & 18.55 \\
\hline 2 & Low (Semi-Skilled) Blue & 8.69 & 8.46 & 10.19 & 7.88 & 13.33 & 7.43 & 13.13 & 10.75 & 15.90 \\
\hline 1 & Unskilled & 15.62 & 15.00 & 19.56 & 55.37 & 67.41 & 54.10 & 21.63 & 16.38 & 27.21 \\
\hline 0 & Unclassified & 1.42 & 1.47 & 0.88 & 1.53 & 2.22 & 1.41 & 1.20 & 1.37 & 1.06 \\
\hline
\end{tabular}

The movement off the farm is evident for the USCT as well, both with respect to the freeborn and the slave-born. As a result, more than half of them were considered unskilled in 1890 , more than double the percentage of any other category. Also of note is the relative exclusion of blacks from high blue-collar occupations. It is somewhat surprising that almost 6 percent of the freeborn are now considered to be white-collar, but this is only eight people. One possible explanation for this result is that veterans of USCT regiments formed by free northern blacks were eligible for federal government jobs following the war. Clearly, a larger sample is required.

\section{Wealth}

The 1870 census reported wealth under two headings, Real Estate and Personal Estate. If the amount was less than $\$ 100$, it was not reported. As Table 7 indicates, over 90 percent of veterans fall into this category. After all, on average, they were in their early 30 s when the census was taken. Nevertheless, making allowance for the small sample size, there are some curious results.

Using the non-Irish Union Army as the comparison group, 93.0 percent report less than $\$ 100$ of personal wealth and 94.8 percent report less than $\$ 100$ of real estate wealth. The percent of the native-born Irish reporting less than $\$ 100$ of personal wealth is one-half a percentage point higher, but that for the foreign-born Irish is five percentage points higher. A similar result is obtained for real estate wealth. There are no Irish that have accumulated personal estate worth 
more than $\$ 5,000$. In the $\$ 100$ to $\$ 5,000$ categories there are over 3.25 times more native-born than foreign-born that report personal estate; for real estate, the relevant ratio is just over 2.25. We do not know how long any of these foreign-born veterans resided in the U.S., but it appears that time in the U.S. is correlated to wealth.

\begin{tabular}{|c|c|c|c|c|c|c|}
\hline \multicolumn{7}{|c|}{ Table 7: Distribution of Personal and Real Estate Wealth in 1870} \\
\hline Personal Estate & $\mathrm{N}$ & $\%<\$ 100$ & $\$ 100<\%<=1,000$ & $\$ 1,000<\%<=5,000$ & $\$ 5,000<\%<=10,000$ & $\%>\$ 10,000$ \\
\hline Non-Irish UA & 13,164 & 93.01 & 5.83 & 1.07 & 0.07 & 0.02 \\
\hline Native & 11,364 & 93.02 & 5.83 & 1.05 & 0.08 & 0.02 \\
\hline Foreign & 1,573 & 94.47 & 4.64 & 0.89 & 0.00 & 0.00 \\
\hline USCT & 1,819 & 89.61 & 10.17 & 0.16 & 0.05 & 0.00 \\
\hline Free & 159 & 91.82 & 8.18 & 0.00 & 0.00 & 0.00 \\
\hline Slave & 1,630 & 89.45 & 10.31 & 0.18 & 0.06 & 0.00 \\
\hline Irish & 1,398 & 95.78 & 3.65 & 0.57 & 0.00 & 0.00 \\
\hline Native & 685 & 93.58 & 5.40 & 1.02 & 0.00 & 0.00 \\
\hline Foreign & 702 & 98.01 & 1.85 & 0.14 & 0.00 & 0.00 \\
\hline Real Estate & $\mathrm{N}$ & $\%<\$ 100$ & $\$ 100<\%<=1,000$ & $\$ 1,000<\%<=5,000$ & $\$ 5,000<\%<=10,000$ & $\%>\$ 10,000$ \\
\hline Non-Irish UA & 13,164 & 94.83 & 1.98 & 2.86 & 0.27 & 0.07 \\
\hline Native & 11,364 & 94.91 & 1.98 & 2.78 & 0.25 & 0.08 \\
\hline Foreign & 1,573 & 95.49 & 1.40 & 2.80 & 0.32 & 0.00 \\
\hline USCT & 1,819 & 95.38 & 3.96 & 0.66 & 0.00 & 0.00 \\
\hline Free & 159 & 91.82 & 5.66 & 2.52 & 0.00 & 0.00 \\
\hline Slave & 1,630 & 95.77 & 3.74 & 0.49 & 0.00 & 0.00 \\
\hline Irish & 1,398 & 95.85 & 2.00 & 2.00 & 0.07 & 0.07 \\
\hline Native & 685 & 94.16 & 3.21 & 2.48 & 0.00 & 0.15 \\
\hline Foreign & 702 & 97.58 & 0.85 & 1.42 & 0.14 & 0.00 \\
\hline
\end{tabular}

The more curious results are those of the USCT. Admittedly, the sample is small. The percentage of blacks reporting personal estate greater than $\$ 100$ is larger than any of the white groups, and the percentages are higher for slave- than freeborn blacks. More research needs to 
be done to determine whether this result remains if the sample size is increased. Successful whites might have paid others to fight in their place, while successful blacks felt a war against slavery was their fight, even if they fought it as a private. Successful whites might have become officers, but blacks were prohibited from holding such ranks.

A similar, albeit less dramatic pattern appears with respect to real estate wealth. The freeborn USCT veterans are much more likely to report real estate, although none report real estate wealth more than $\$ 5,000$. This may be less curious in that the USCT came from, and returned to, rural areas. Also, by this time, former slaves were beginning to acquire land. Was land ownership somehow tied to improved health? ${ }^{16}$ That is a question for further research.

One disappointing feature of our data is that a similar snapshot of wealth-holding is unavailable at a later date for these veterans. What we can observe later in their lives is the distribution between homeowners and renters. Table 8 reports the division for 1900 when they were, on average, in their early $60 \mathrm{~s}$, and each group was experiencing some mortality.

\begin{tabular}{|c|c|c|c|}
\hline Table 8: Owners vs & Renters in 1900 \\
\hline & & & \\
\hline Non-Irish UA & 7,998 & 72.53 & 27.47 \\
\hline Native & 6,931 & 72.13 & 27.87 \\
\hline Foreign & 981 & 75.03 & 24.97 \\
\hline & & & \\
\hline USCT & 924 & 42.21 & 57.79 \\
\hline Free & 72 & 50.00 & 50.00 \\
\hline Slave & 840 & 41.55 & 58.45 \\
\hline & & & \\
\hline Irish UA & 778 & 68.77 & 31.23 \\
\hline Native & 449 & 68.60 & 31.40 \\
\hline Foreign & 323 & 68.42 & 31.58 \\
\hline
\end{tabular}

This table is consistent with what might be expected. The group with the highest percentage of owners was the non-Irish whites, with the Irish about four percentage points below, but considerably above the percentages for blacks. The freeborn veterans of the USCT are almost 20 percentage points below the Irish, and they are evenly divided between owners and renters. Slave-born veterans are much more likely to rent than own, the opposite pattern of the whites. The wealth data suggests some black individuals did relatively well. How well and why they chose to join the USCT remains to be determined. 


\section{Rated Conditions and Cause of Death}

U.S. Pension Bureau surgeons were instructed to rate veterans with respect to 20 different conditions that are listed in the left column of Table 9. The percentage of veterans in each group who were ever diagnosed with each condition is reported in the table. ${ }^{17}$

\begin{tabular}{|c|c|c|c|c|c|c|c|c|c|}
\hline \multicolumn{10}{|c|}{ Table 9: Percentage of Recruits Rated for Condition ${ }^{1}$} \\
\hline \multirow[t]{2}{*}{ Condition } & \multicolumn{3}{|c|}{ Non-Irish UA } & \multicolumn{3}{|c|}{ USCT } & \multicolumn{3}{|c|}{ Irish } \\
\hline & Total & Native & Foreign & Total & Free & Slave & Total & Native & Foreign \\
\hline $\mathrm{N}$ & 13,514 & 11,168 & 2,104 & 1,623 & 135 & 1,461 & 1,368 & 665 & 688 \\
\hline rheumatism & 53.71 & 53.99 & 52.66 & 64.08 & 69.63 & 64.20 & 52.41 & 53.83 & 51.45 \\
\hline cardio & 45.29 & 46.79 & 37.83 & 37.58 & 40.74 & 37.58 & 44.37 & 49.02 & 39.68 \\
\hline injury & 32.09 & 32.06 & 31.94 & 32.84 & 38.52 & 32.24 & 39.25 & 34.74 & 43.75 \\
\hline hemorrhoid & 26.67 & 28.23 & 19.01 & 17.07 & 20.00 & 16.77 & 23.32 & 29.92 & 16.72 \\
\hline respiratory & 27.30 & 28.18 & 23.38 & 18.24 & 26.67 & 17.66 & 25.15 & 26.92 & 23.11 \\
\hline general app & 21.10 & 21.19 & 21.15 & 28.59 & 27.41 & 28.88 & 22.44 & 20.90 & 23.98 \\
\hline diarrhea & 22.21 & 23.43 & 15.92 & 5.73 & 11.85 & 5.07 & 18.13 & 24.36 & 12.06 \\
\hline eye & 18.48 & 18.30 & 19.58 & 25.57 & 26.67 & 25.39 & 18.13 & 17.74 & 18.17 \\
\hline hernia & 15.84 & 15.55 & 17.54 & 13.19 & 11.11 & 13.35 & 15.20 & 14.74 & 15.99 \\
\hline ear & 14.94 & 14.66 & 16.54 & 7.02 & 2.22 & 7.46 & 12.50 & 12.33 & 12.79 \\
\hline gastro & 13.79 & 14.45 & 10.93 & 6.47 & 12.59 & 5.95 & 13.74 & 18.20 & 9.74 \\
\hline nervous & 13.13 & 13.49 & 11.45 & 7.02 & 5.93 & 7.26 & 11.26 & 11.58 & 10.90 \\
\hline genitourinary & 11.40 & 11.90 & 8.98 & 9.00 & 12.59 & 8.49 & 9.36 & 10.98 & 7.99 \\
\hline varicose & 7.30 & 6.82 & 9.70 & 3.51 & 5.93 & 3.29 & 8.11 & 5.71 & 10.47 \\
\hline liver & 6.73 & 7.05 & 5.42 & 2.40 & 4.44 & 2.26 & 5.77 & 7.52 & 4.07 \\
\hline infectious & 5.51 & 5.58 & 4.90 & 2.28 & 1.48 & 2.40 & 6.07 & 4.81 & 7.27 \\
\hline neoplasm & 1.53 & 1.54 & 1.52 & 2.46 & 0.74 & 2.67 & 1.17 & 0.90 & 1.45 \\
\hline spleen & 0.67 & 0.72 & 0.48 & 0.25 & 0.74 & 0.21 & 0.95 & 0.45 & 1.45 \\
\hline endocrine & 0.63 & 0.70 & 0.29 & 0.31 & 0.74 & 0.27 & 0.58 & 0.60 & 0.58 \\
\hline gallbladder & 0.02 & 0.02 & 0.05 & 0.00 & 0.00 & 0.00 & 0.07 & 0.15 & 0.00 \\
\hline
\end{tabular}

Notes:

${ }^{1}$ Sub-group totals do not equal sum of parts because birthplace was not available for all recruits.

Overall, the white troops, non-Irish and Irish, are very similar. There are some differences between the foreign- and native-born Irish, but they too are very similar on the whole. With respect to the conditions where at least 10 percent of the population has been rated, the Irish are never more than, say, 20 percent different from the non-Irish, and often much closer. There are only a few differences between the two subgroups of Irishmen. The native-born were twice as likely to be rated with chronic diarrhea than the foreign-born, 84 percent more likely to be rated with a gastro-intestinal condition, and 76 percent more likely to be rated with hemorrhoids. Why this should be true requires further research. 
With respect to the blacks, the percentages are generally less than either of the two white groups with a few exceptions. The blacks were about a fifth more likely to be rated with rheumatism and a third more likely to be rated with an eye condition or a poor general condition than the whites. The whites were less likely to be rated with a cardiovascular condition than native-born whites, non-Irish or Irish. This is the opposite of contemporary data which shows blacks much more likely to have cardiovascular disease than whites. ${ }^{18}$ Both cardiovascular conditions and rheumatism received a gradation with the rating (the higher the rating, the higher the pension). Other things equal, whether blacks received a reduced rating for rheumatism while whites received an inflated rating for cardiovascular (and the likelihood of a higher pension) need to be studied. With the exception of general appearance and hernia, for each condition for which at least 10 percent of freeborn blacks were rated, slave-born blacks were less likely to receive a rating. With the exception of rheumatism, an eye condition, or a poor general condition, blacks were about two-thirds as likely as whites to receive a rating. When this is broken down between freeborn and slave-born, the average percentage for the residual conditions for each group divided by the average percentage for the non-Irish whites become 80 percent and 66 percent, respectively. The lack of ratings for blacks veterans might suggest blacks were healthier, but it is more likely explained by discrimination. ${ }^{19}$

The information on death-by-cause raises questions similar to those from the ratings data. A cardiovascular condition is the leading cause of death in each group and subgroup accounting for over 30 percent of deaths in whites and freeborn blacks. Curiously, slave-born blacks have a greater than six percentage point lower incidence of a cardiovascular condition being reported as the cause of death than any white subgroup and over four percentage point lower incidence than freeborn blacks. Since it was most unlikely that the surgeon completing the report for the Pension Bureau was the same person as the doctor signing the death certificate, there is unlikely to be a direct relationship here. However, the fact a veteran received a rating (and a pension) for a particular condition may have influenced what was listed as the cause of death. This requires additional research. 


\begin{tabular}{|c|c|c|c|c|c|c|c|c|c|}
\hline \multicolumn{10}{|c|}{ Table 10: Cause of Death ${ }^{1}$} \\
\hline \multirow{2}{*}{ Condition } & \multicolumn{3}{|c|}{ Non-Irish UA } & \multicolumn{3}{|c|}{ USCT } & \multicolumn{3}{|c|}{ Irish } \\
\hline & Total & Native & Foreign & Total & Free & Slave & Total & Native & Foreign \\
\hline $\mathrm{N}$ & 8,917 & 7,306 & 1,438 & 1,060 & 100 & 938 & 893 & 427 & 456 \\
\hline cardio & 33.12 & 33.59 & 31.78 & 26.13 & 30.00 & 25.69 & 31.58 & 32.32 & 31.36 \\
\hline respiratory & 12.68 & 12.54 & 13.00 & 16.32 & 10.00 & 17.16 & 14.45 & 13.58 & 14.91 \\
\hline infectious & 10.72 & 10.62 & 10.78 & 15.19 & 17.00 & 14.93 & 11.42 & 9.84 & 12.72 \\
\hline genitourinary & 9.44 & 9.57 & 8.90 & 11.13 & 10.00 & 11.30 & 10.41 & 12.41 & 8.77 \\
\hline nervous & 5.51 & 5.56 & 5.29 & 4.72 & 5.00 & 4.58 & 4.93 & 5.15 & 4.82 \\
\hline general app & 5.46 & 5.37 & 6.05 & 8.02 & 7.00 & 8.21 & 4.14 & 4.22 & 3.95 \\
\hline gastrointestinal & 5.44 & 5.39 & 5.84 & 3.40 & 1.00 & 3.73 & 3.92 & 3.75 & 3.73 \\
\hline neoplasm & 4.97 & 4.78 & 6.12 & 1.70 & 4.00 & 1.49 & 4.93 & 4.92 & 4.82 \\
\hline injury & 4.07 & 3.91 & 4.52 & 4.81 & 8.00 & 4.48 & 5.94 & 5.15 & 6.80 \\
\hline diarrhea & 3.50 & 3.71 & 2.09 & 3.40 & 2.00 & 3.30 & 4.14 & 4.68 & 3.73 \\
\hline other & 2.00 & 1.97 & 2.09 & 1.60 & 2.00 & 1.60 & 2.24 & 2.11 & 2.41 \\
\hline rheumatism & 1.14 & 1.04 & 1.60 & 2.08 & 3.00 & 2.03 & 0.78 & 0.70 & 0.88 \\
\hline endocrine & 1.10 & 1.16 & 0.70 & 0.85 & 1.00 & 0.85 & 0.67 & 0.94 & 0.44 \\
\hline suicide & 0.64 & 0.57 & 1.04 & 0.19 & 0.00 & 0.21 & 0.45 & 0.23 & 0.66 \\
\hline liver & 0.12 & 0.12 & 0.14 & 0.38 & 0.00 & 0.32 & 0.00 & 0.00 & 0.00 \\
\hline ear & 0.04 & 0.05 & 0.00 & 0.00 & 0.00 & 0.00 & 0.00 & 0.00 & 0.00 \\
\hline spleen & 0.02 & 0.03 & 0.00 & 0.00 & 0.00 & 0.00 & 0.00 & 0.00 & 0.00 \\
\hline eye & 0.02 & 0.01 & 0.07 & 0.09 & 0.00 & 0.11 & 0.00 & 0.00 & 0.00 \\
\hline
\end{tabular}

Notes:

${ }^{1}$ Sub-group totals do not equal sum of parts because birthplace was not available for all recruits

Respiratory conditions and infectious diseases were the second and third most common death causes for non-Irish whites. This was true for the Irish as well, but genito-urinary conditions were a close fourth for the combined group. For the native-born Irish, genito-urinary conditions were more common than infectious diseases. For freeborn blacks, infectious diseases were the second most common cause with an incidence 50 percent above either of the white groups. Infectious diseases were also a more common cause for slave-born blacks, but it ranked behind respiratory disease. Slave-born blacks had the largest incidence of respiratory disease; freeborn blacks, the lowest. The reasons for that require more research.

Given the lower incidence of cardiovascular causes among blacks, other causes will assume greater importance. Relative to the non-Irish, blacks were more likely to die from any of the next three ranked conditions: respiratory conditions, infectious diseases, and genito-urinary conditions. The incidence of rheumatism and general appearance as a death cause are also higher, but the percentages are low. Freeborn blacks were also more likely to die of injuries. On 
the other hand, blacks were much less likely than the white groups to be reported dying of neoplasms. Given that many of these are likely to have been skin cancers, this isn't surprising.

Like the blacks, the Irish have greater incidences of respiratory conditions, infectious diseases, and genito-urinary conditions. The former two are more prominent in the foreign-born Irish; the latter, in the native-born Irish. To the extent that respiratory conditions and infectious diseases are a reflection of people living in dense and less affluent conditions, it may help explain the higher incidence among these groups. It may also explain the lower incidence of cardiovascular disease, but it cannot explain the entire difference. Much more work is required to understand the patterns in these two tables, especially the smaller percentage of blacks reported as dying from cardiovascular conditions.

\section{Survival Rates}

Death information exists for many of the veterans in the various groups, and this permits the construction of survival curves for each subgroup. It is important to keep in mind that these are not survival curves for the male cohort born ca. 1840; these are the survival curves of groups of men healthy enough to be inducted into the Union Army and lucky enough to survive the insults of battle and disease during the war. Since most of the information about death places is found in the pension records, they are biased by those veterans who survived until 1890. Before that date, when the law creating a service pension was passed, disability pensions were awarded to those who were severely injured and impaired during the Civil War. Roughly half the veterans in the panel were not eligible for a pension initially, and may not have been able to apply under the service pension law, especially if they died before 1890. Since many veterans did not enter the pension system until after 1890, the sample found in the death records is more representative of those veterans who survived until then.

Because the average year of birth varies widely across the three large groups, the curves are arranged so that the horizontal axis is age as opposed to year. Given that the average nonIrishman was born in 1837 (rounding to the nearest whole year), they are 29 in 1866; the USCT did not become 29 on average until 1867.

The USCT have the worst experience, with the difference between that group and the others widening. Although survival curves for the subgroups are not reported here, the reason 
for this is associated with the slave-born USCT. The freeborn have survival rates $6-8$ percent higher the slave-born until they reach their early $80 \mathrm{~s}$. A similar pattern is true among the Irish where the native-born have higher rates than the foreign-born until about the same age (early 80s). The freeborn USCT and foreign-born non-Irish have the highest survival rates at young ages. Their survival begins to fall below the native-born non-Irish in their late 50s. What is evident in both versions of the figure is that the experience of the US-born non-Irish whites is typically at or near the best. More detail can be found in calculation of hazard ratios.

Figure 7A depicts survival curves by year $(1865=1)$ for the three major groups. The Irish seem to have more or less the same experience as the non-Irish until about 1908, then their survival falls quickly. This is about when you would expect the great difference in average birth years to have its effect; 1904 is the year the average foreign-born Irish veteran turned 70. The USCT, who are approximately the same age as the others, have lower survival rates.

\section{Figure 7A: Survival Rates by Year $(1865=1)$}

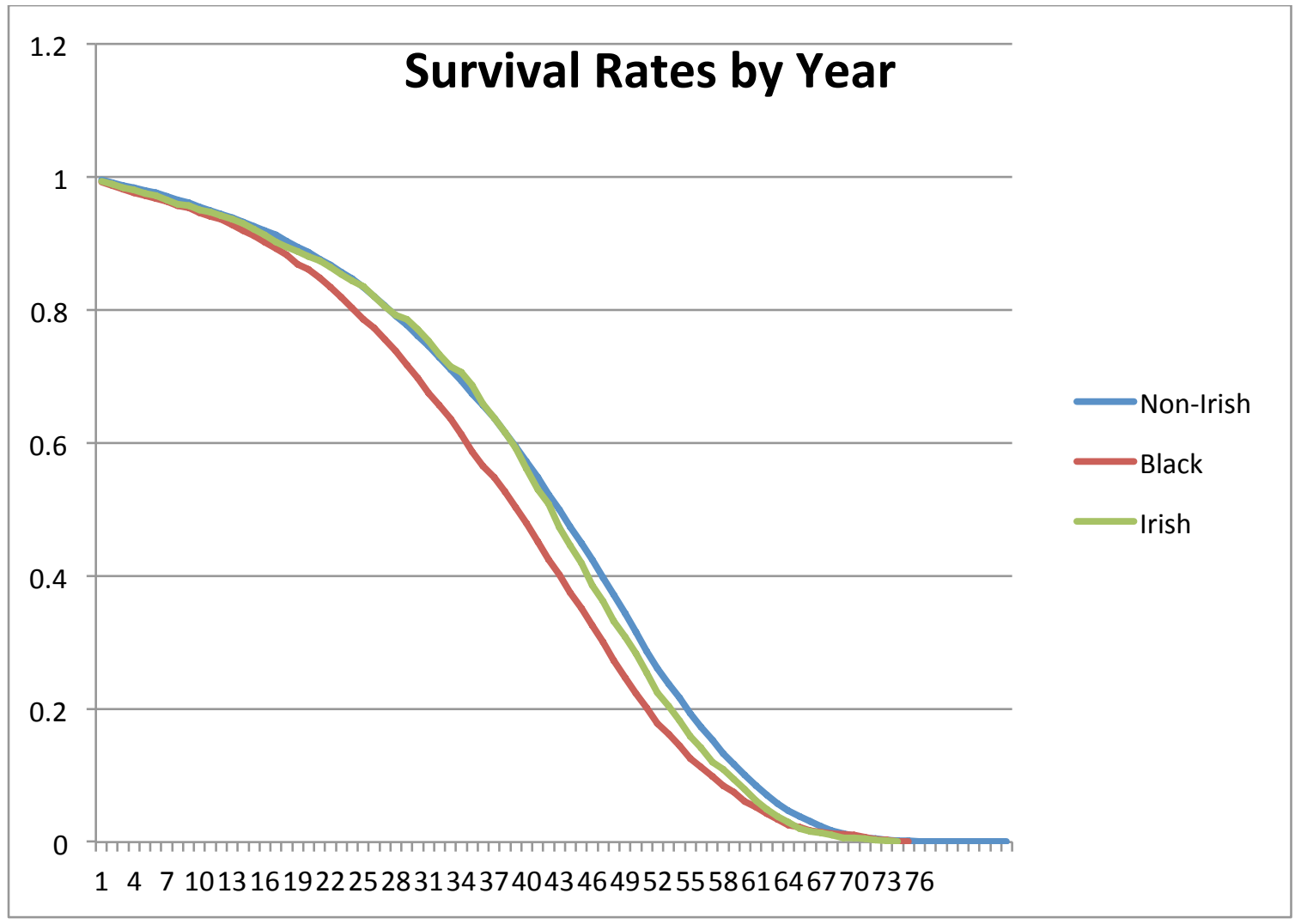


In Figure 7B, the curves in Figure 7A have been adjusted so that the horizontal axis is age as opposed to year. We shifted the Irish and black groups to the right or the left so, on average, they match the average age of the non-Irish, who again serve as our comparison group. Given that the average non-Irishman was 29 in 1866 and the average member of the USCT did not become 29 until 1867, those curves have been shifted by one year to the left. The result is Figure $7 \mathrm{~B}$.

Figure 7B: Survival Rates by Average Birth Year (adjusted for age in 1840)

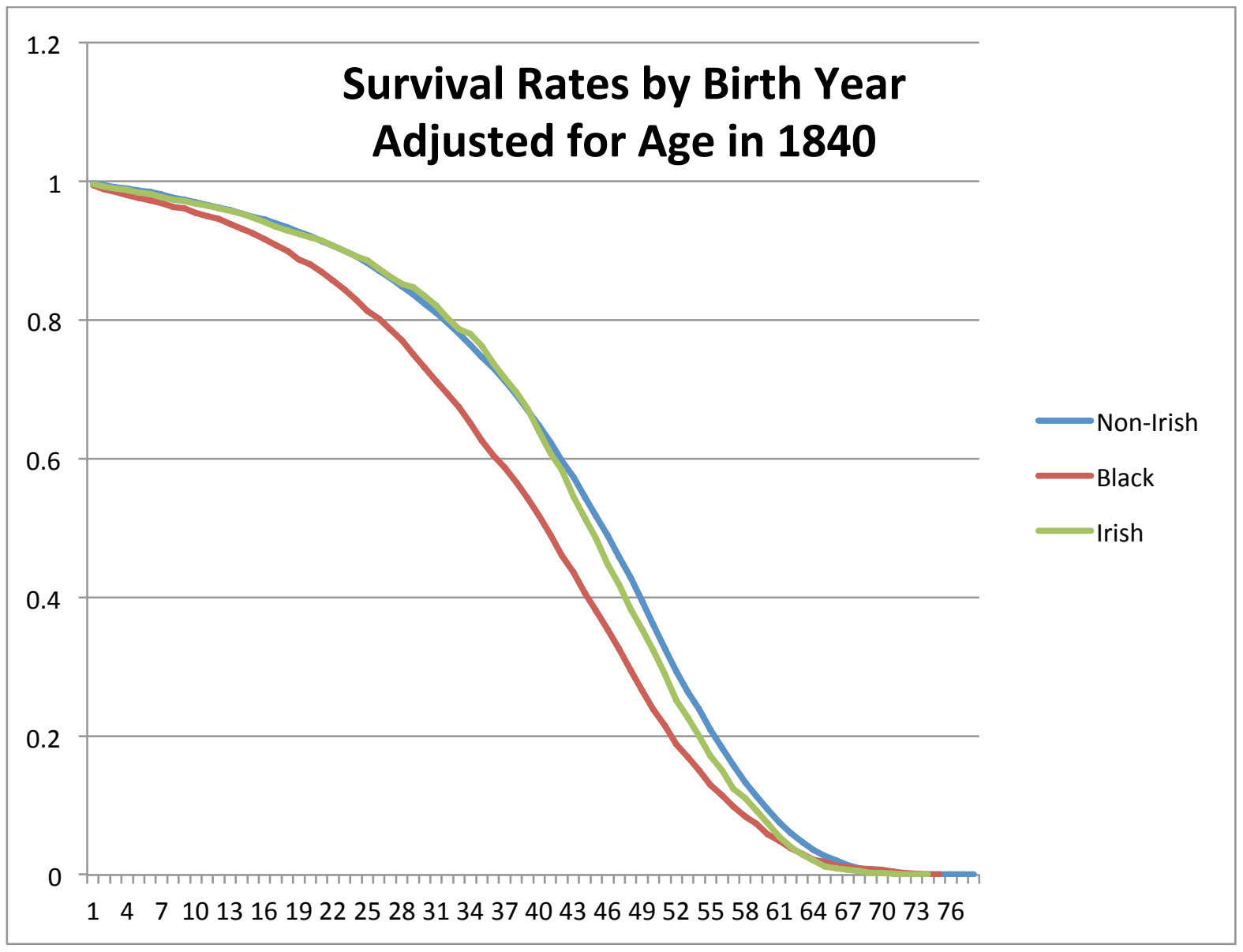

\section{Hazard Ratios}

We calculated hazard ratios using a pooled logistic regression model for the discrete time hazards in the surgeons' certificates. ${ }^{20}$ The results are in Table 11 below. We adopted 1890 as the baseline; the regressions are defined to include only those veterans who were alive in 1890, whether they received a pension before that year or not. This additional limitation is necessary 
given that a significant portion of our "final sample" was not eligible for a pension until the reforms of 1890, and we do not necessarily know which of them died before 1890. In these regressions, the dependent variable is a time-dependent indicator for having died in a particular year during or after 1890. Controls include age in 1840 (the hazard ratio increases at approximately 10 percent for each additional year a veteran lived) and a cubic time trend. Coefficients with a $\mathrm{P}$ value less than 10 percent are highlighted in red and boldface.

Regression I includes only an indicator for which population group a veteran belonged. The omitted group is the native-born non-Irish whites; foreign-born non-Irish whites are included as a separate group and have a ratio a little less than 10 percent higher. Slave-born blacks had a higher ratio (1.246) than freeborn blacks (1.197). That for foreign-born Irish, the first generation in the US, was 1.219 , slightly less than that for slave-born blacks. Finally, the other native-born Irish had a hazard ratio roughly 8 percent higher than native-born non-Irish. As more and more control variables are added to this basic regression, the ratio that retains $\mathrm{P}$ values of 10 percent or less (those in bold) are the slave-born blacks. It remains high in every specification.

Regression II adds a set of controls for place. Urban (large) indicates a place larger than 50,000 in the 1860 census; urban (small) indicates a place larger than 10,000 but less than 50,000 ; and foreign is outside the U.S. The omitted group is a rural place. The places reflect three distinct time points in a veteran's life: where they were born, where they enlisted, and where they died. The urban mortality penalty is immediately evident in that the urban coefficients are generally greater than one, and urban (large) is typically greater than urban (small). ${ }^{21}$ Further, even as additional controls are added, these results persist. Consistent with the findings of Cain and Hong, a foreign birthplace is as hazardous as a large American city, but there are too few veterans with foreign death places to be able to say they were in any manner different than the others.

A series of controls reflecting the person's life around the time of enlistment is added in regression III. The first is a set of occupational variables reflective of those reported in Aim 3 above. The omitted group is the unskilled. High-skilled blue collar workers had a lower hazard than any of the other occupational groups. The hazard ratios for high-skilled white collar workers ranked second best. An early enlistment year increased one's hazard as did being wounded during the war. Being tall, being sick during the war, surviving life in POW camps, and beginning one's service as a private did little to one's hazard. That said, an increase of one 
inch in height increased one's hazard by a little over 1 percent. This is somewhat surprising and needs further investigation.

\begin{tabular}{|c|c|c|c|c|}
\hline \multicolumn{5}{|c|}{ Table 11: Hazard Ratio Regressions } \\
\hline & I & II & III & IV \\
\hline Group & Odds Ratio & & & \\
\hline UA (foreign) & $1.089 * *$ & 1.184 & 1.14 & 1.134 \\
\hline Black (free) & 1.197 & 1.169 & 1.112 & 1.108 \\
\hline Black (slave) & $1.246 * * *$ & $1.102+$ & $1.168^{*}$ & $1.193^{* *}$ \\
\hline Irish (native) & $1.082^{*}$ & 1.082 & 1.06 & 1.053 \\
\hline Irish (foreign) & $1.219 * * *$ & 1.279* & 1.241 & 1.209 \\
\hline Birthplace & & $1.145^{*}$ & $1.137+$ & 1.129+ \\
\hline Urban (large) & & $1.106+$ & 1.089 & 1.134* \\
\hline Urban (small) & & 1.031 & 1.081 & 1.096 \\
\hline \multicolumn{5}{|l|}{ Enlis tment } \\
\hline Urban (large) & & $1.125 * *$ & 1.037 & 1.026 \\
\hline Urban (small) & & 1.008 & 0.999 & 0.978 \\
\hline \multicolumn{5}{|l|}{ De athplace } \\
\hline Urban (large) & & $1.500 * * *$ & $1.486 * * *$ & $1.437 * * *$ \\
\hline Urban (small) & & $1.167 * * *$ & $1.144 * *$ & $1.128 *$ \\
\hline Foreign & & 1.106 & 0.945 & 1.017 \\
\hline \multicolumn{5}{|l|}{ Occupation } \\
\hline Unclassified & & & 1.15 & 1.123 \\
\hline Unskilled & & & omitted & omitted \\
\hline Low Blue Collar & & & 1.071 & 1.081 \\
\hline Farmer & & & 0.957 & 0.964 \\
\hline High Blue Collar & & & $0.822 * * *$ & $0.826 * * *$ \\
\hline Low White Collar & & & 0.938 & 0.945 \\
\hline High White Collar & & & $0.862^{*}$ & $0.876+$ \\
\hline \multicolumn{5}{|l|}{ Enlis tment } \\
\hline 1860 & & & 0.936 & 0.93 \\
\hline 1861 & & & $1.074+$ & $1.076+$ \\
\hline 1862 & & & $1.089^{*}$ & 1.092* \\
\hline 1863 & & & 0.977 & 0.965 \\
\hline 1864 & & & (omitted) & (omitted) \\
\hline
\end{tabular}




\begin{tabular}{|c|c|c|c|c|}
\hline height & & & $1.012^{*}$ & $1.011+$ \\
\hline illness & & & 0.993 & 0.99 \\
\hline wound & & & 1.026 & 1.023 \\
\hline POW & & & 1.055 & 1.06 \\
\hline Initial rank: Private & & & 0.962 & 0.958 \\
\hline \multicolumn{5}{|l|}{ Rated for: } \\
\hline cardiovascular & & & & 0.93 \\
\hline diarrhea & & & & 0.967 \\
\hline ear & & & & $1.830 * * *$ \\
\hline kidney-endocrine & & & & (omitted) \\
\hline eyes & & & & 0.817 \\
\hline gastro-intestinal & & & & $0.795^{* *}$ \\
\hline general appearance & & & & $2.122 *$ \\
\hline genito-urinary & & & & 0.941 \\
\hline rectum-hemorroids & & & & 1.276 \\
\hline infectious disease & & & & 1.212 \\
\hline wounds & & & & 1.169* \\
\hline liver & & & & 0.839 \\
\hline spleen & & & & (omitted) \\
\hline gall bladder & & & & (omitted) \\
\hline tumor & & & & (omitted) \\
\hline nervous system & & & & 1.393 \\
\hline rectum-hemoroids & & & & 1.178 \\
\hline pulmonary & & & & 1.28 \\
\hline rheumatism, & & & & 1.02 \\
\hline vericose veins & & & & 2.191* \\
\hline age 1840 & $1.093 * * *$ & $1.108 * * *$ & $1.108^{* * *}$ & $1.107^{* * *}$ \\
\hline $\mathrm{t}$ & $2.059 * * *$ & $1.716 * * *$ & $1.709 * * *$ & $1.763 * * *$ \\
\hline $\mathrm{t} 2$ & $0.987 * * *$ & $0.991 * * *$ & $0.991 * * *$ & $0.991 * * *$ \\
\hline $\mathrm{t} 3$ & $1.000 * * *$ & $1.000 * * *$ & $1.000 * * *$ & $1.000 * * *$ \\
\hline $\mathrm{N}$ & 773,017 & 362,032 & 329,845 & 304,499 \\
\hline pseudo-r ${ }^{2}$ & 0.2419 & 0.2509 & 0.2537 & 0.2551 \\
\hline
\end{tabular}

The final set of controls added in regression IV reflect conditions with which a veteran could be rated as part of the Union Army pension program. Everything else equal, the highest hazards were for a poor general appearance or varicose veins. Why this should be true is unclear. Why a gastro-intestinal condition was, on average, protective is also unclear. Ear 
(deafness) and wounds were the other two conditions with p-values less than 10 percent. Fogel et al. suggests there was little difference between those rated for wounds who were wounded during the war (hence eligible for a pension before 1890) and those rated for wounds who were not wounded during the war. ${ }^{22}$

With all these controls in place, foreign-born non-Irish whites had a hazard ratio 13 percent higher than US-born non-Irish whites. Freeborn blacks had a hazard ratio roughly 10 percent higher and slave-born blacks had a hazard ratio roughly 20 percent higher than US-born non-Irish whites. First-generation Irish had a hazard ratio in 20 percent higher; while the nativeborn with Irish surnames were but 5 percent higher than their non-Irish counterparts. Most of these differences are not statistically different from zero. Nonetheless, the suspicion is that early life conditions in the southern United States and Ireland were substantially different than those in the northern United States. Understanding such differences is necessary if one wants to understand the health outcomes of these two ethnic groups.

\section{Conclusion}

Joel Mokyr opined that blacks in Boston may well have done better than the Irish in the years before the Civil War. The results of this investigation suggest that well may be true if the comparison is between blacks born in the North and Irish migrants. While the bottom half of the occupational distribution of both groups was largely unskilled, the proportion of freeborn blacks in high (but not low) white-collar occupations in 1890 than foreign-born Irish, but this is based on an extremely small sample. On the other hand, unskilled Irish initially provided the unskilled labor for the burgeoning industrial firms of New England, whereas blacks were generally excluded until the twentieth century. For this cohort of USCT veterans, their unskilled labor was likely to take quite a different form.

Our evidence suggests that the native-born Irish were very much like their non-Irish white counterparts. They moved west at about the same time; they had similar survival rates and not very different hazard ratios. There is, however, a suggestion that the benefits they received did not rise as quickly as for the non-Irish. There is clear evidence that their foreign-born brethren lagged behind. The foreign-born began their western migration a bit later and smaller proportions migrated when they did leave the familiar confines of the East Coast. Some became 
farmers, but, of those obtaining other skills, they were more likely to move into blue-collar occupations tied to industry. Their survival pattern was slightly different, and their hazard ratios a bit higher. Whatever disparities and prejudice faced the native-born Irish, it was seemingly worse for the foreign-born.

The blacks born in slave states, some of whom may have actually been free blacks, had the hardest path to trod. They were largely unskilled and overwhelmingly penniless. The generation who joined the USCT did show some northward movement, but it was cautious at best. When they became eligible for the pension, they were almost 10 percentage points less likely to be rated with a cardiovascular condition, than whites, and, while rheumatism is a relatively rare cause of death, it is at least twice as likely to appear for black veterans. A cardiovascular condition is the most common cause of death, but slave-born blacks are less likely to have that listed on the death certificates as whites and freeborn blacks. Why this should be true is unclear; was it part of a pattern of differential diagnosis that led to slave-born blacks receiving lower pensions than others? They were scarred by their experiences before the war, and their prospects after the war were little improved.

The blacks born in free states, however, are a revelation. While roughly half the group are little different than their southern brethren, the other half contains people who seemingly did quite well. Much more research needs to go into discovering how they moved into high whitecollar positions, and why, despite what must have been family origins in slavery, their generation has survival rates and hazard ratios similar to non-Irish whites. There is no evidence, with so few of them in the North, they were accepted as "right folks" (in Tom Lehrer's terminology). There is evidence they suffered increasing discrimination when the Great Migration brought the slave-born blacks north. It could be that, since discrimination forbade blacks from being officers in the USCT, we simply do not have their white counterparts in these databases.

In short, the statistical evidence does not reveal disparate outcomes for all blacks and Irish, but there is evidence of inferior outcomes for slave-born blacks and foreign-born Irish. For the freeborn blacks and native-born Irish, for whom the historical tradition suggests discrimination and prejudice, the statistical evidence only hints at such problems. More digging is required to learn how real they were. 
${ }^{1}$ Hoyt Bleakley is an Associate Professor in the Booth School of Business at the University of Chicago; Louis Cain is a Professor of Economics at Loyola University Chicago and an Adjunct Professor of Economics at Northwestern University; Joseph Ferrie is a Professor of Economics at Northwestern University. All of them have an affiliation with the Center for Population Economics at the University of ${ }^{2}$ Richard Jensen, "'No Irish Need Apply': A Myth of Victimization," Journal of Social History 36.2 (2002) 405-429. A song with that title was published in London in 1862.

${ }^{3}$ See Joseph P. Ferrie, Yankeys Now: Immigrants in the Antebellum U.S., 1840-1860 (New York: Oxford University Press, 1999), p. 161.

${ }^{4}$ Oscar Handlin, Boston's Immigrants (New York: Athenaeum, 1977), p. 70

${ }^{5}$ This is reported for New York in Ronald H. Bayor and Timothy J. Meagher, The New York Irish (Baltimore: Johns Hopkins University Press, 1996).and for Boston in James Oliver Horton and Lois E. Horton. Black Bostonians: Family Life and Community Struggle in the Antebellum North (New York: Holmes and Meier, 1979).

${ }_{7}^{6}$ Joel Mokyr, Why Ireland Starved (London: George Allen \& Unwin, 1983), p. 254.

${ }^{7}$ The data set has been shown to be representative of white Northern men who served in the Civil War, and more generally, of white, Northern men who became adults during the 1860s. Robert W. Fogel and Dora L. Costa, "A Theory of Technophysio Evolution, with Some Implications for Forecasting Population, Health Care Costs, and Pension Costs," Demography 34(1) 1997, "The Demography of Aging."

${ }^{8}$ The work reported in this essay comes from a pilot study; the CPE is currently enlarging both databases.

${ }^{9}$ We also subtracted those who died after the Civil War ended while still in the Army.

${ }^{10}$ The 1841 Irish census was consulted, but many of the most common names found in that census are not ethnically Irish (e.g., Smith).

${ }^{11}$ Defining Irish in this manner means that it is possible that some with Irish surnames can be found in the USCT both because some slaves took the surnames of their former masters and because USCT companies included some white sergeants and other non-commissioned officers. These numbers are thought to be quite small, and we have not attempted for the purpose of this paper to attempt to identify and remove them.

${ }^{12}$ One would expect only a small number in these cells; the zeros are likely the result of a small sample size.

${ }^{13}$ Joseph T. Glatthaar, Forged in Battle: The Civil War Alliance of Black Soldiers and White Officers (New York and London: The Free Press, 1990); Horton and Horton, Black Bostonians; and Leonard P. Curry, The Free Black in Urban America, 1800-1850 (Chicago: University of Chicago Press, 1981). ${ }^{14}$ The tabulations of the 1841 Irish census and the 1840s ship registers in New York are based on Mokyr, Why Ireland Starved, Tables 8.7 and 8.8, pp. 248-49.

${ }^{15}$ The percentage of farmers in the ship registers for the 1840s (1840-48) is roughly half that in the 1841 census. This was likely to have changed once the famine struck.

${ }^{16}$ Information on landholding by free urban blacks in the antebellum period can be found in Curry, The Free Black in Urban America, 1800-1850, while W. E. B. DuBois, The Philadelphia Negro: A Social Study (Philadelphia: University of Pennsylvania, 1899) has information concerning that city.

${ }^{17}$ These data are subject to several biases. Veterans who got on the pension rolls early (before 1890) as a result of an injury are less likely to have chronic condition listed as are veterans who got on the pension rolls for reaching age 65 under the 1907 law. Most blacks were placed on the rolls as a result of the 1890 law (they had a chronic condition) or the 1907 age law. Whites are more likely to be on because of the General Law (war-related disability) before 1890. This may lead to a different set of conditions being given and an underestimation among blacks if more are receiving a pension as a result of their age. A detailed analysis of black-white differentials based on this data can be found in Dora L. Costa, Lorens A. Helmchen, and Sven Wilson, "Race, Infection, and Arteriosclerosis in the Past," Proceedings of the National Academy of Sciences, vol. 104, no. 33, August 14, 2007. 
${ }^{18}$ See, for example, Donald A. Barr, Health Disparities in the United States: Social Class, Race, Ethnicity, and Health (Baltimore: The Johns Hopkins University Press, 2008); Carol J. R. Hogue, Martha A. Hargraves, and Karen Scott Collins, eds., Minority Health in America: Findings and Policy Implications from the Commonwealth Fund Minority Health Survey (Baltimore: The Johns Hopkins University Press, 2000); or Raymond M. Nakamura, Health in America: A Multicultural Perspective (Boston: Allyn and Bacon, 1999).

${ }^{19}$ The percentage distribution for the subcategories of cardiovascular reveal three major differences between white and black: impaired circulation, palpitations and, especially, cyanosis. Because cyanosis is identified by a bluish skin color, it is much harder to discover on darker-pigmented skins. However, this explains less than half the difference between white and black.

${ }^{20}$ There are well-defined problems that emerge when this specification is used with a fixed population. Each group has a survivor rate of 1 at the start, and they each have a rate of 0 by some year.

${ }^{21}$ See Louis Cain and Sok Chul Hong, "Survival in 19th Century Cities: The Larger the City, the Smaller Your Chances," Explorations in Economic History, October 2009, for a discussion of the urban mortality penalty.

${ }^{22}$ Robert Fogel, Louis Cain, Joseph Burton, and Brian Bettenhausen, "Was What Ail'd Ya' What Kill'd Ya'?," Economics \& Human Biology, online December 2012, suggests there was little difference between those rated for wounds who were wounded during the war, hence eligible for a pension before 1890, and those rated for wounds who were not wounded during the war. 